\title{
洗浄現象の界面科学的解析
}

\section{Role of Interfacial Phenomena in Detergency Process}

後 藤 景 子

\section{1. 污れの脱離・再付着と自由エネルギー変化}

一般に、洗浄は液体中で行われる。洗浄過程の第一段階 は液体による被洗物のぬれであり、続いて污れが脱離し、 さらに脱離した污れの一部が再付着することがある。した がって、洗浄を効果的に行うには、好や污れの脱離を促 進し、污れの再付着を抑制する必要があり、このために通 常、洗凨や機械力を付与する ${ }^{1)}$ 。

界面科学的立場からは、污れの脱離や再付着は界面の消 失や生成に他ならない。すなわち、污れが脱離するとき、 基質/污れ界面が消失し、基質/液体界面と污れ/液体界面 が生成する。このときの自由エネルギー変化 $\Delta \mathrm{G}_{\mathrm{R}}$ は次式 で与えられる2)。

$$
\Delta \mathrm{G}_{\mathrm{R}}=\gamma_{13}+\gamma_{23}-\gamma_{12}
$$

ここで $\gamma$ は界面自由エネルギー、下添字 1,2 および 3 はそ れぞれ污れ、基質および夜体を表す。

一方、污れが再付着する場合、基質/液体界面と污れ/ 液体界面が消失し、基質/污れ界面が生成する。したがっ て污れ付着に伴う自由エネルギー変化 $\Delta \mathrm{G}_{\mathrm{D}}$ は $\Delta \mathrm{G}_{\mathrm{R}}$ と大き さが同じで反対符号をもつことになる。これらの自由エネ ルギー変化は、脱離や再付着の際に必要な仕事量に相当す るから、 $\Delta \mathrm{G}_{\mathrm{R}}$ が小さく、 $\Delta \mathrm{G}_{\mathrm{D}}$ が大きいほど洗浄に有利に なる。

\section{2. 表面自由エネルギーを用いた油污れの脱離現象の解析}

著者らは水晶振動子 $(\mathrm{QCM})$ 上にポリエチレンおよびナ イロン 6 膜をスピンコートする方法でよく規定されたモデ ル基質を作製し、污れの脱離や再付着に伴う QCM の共振 周波数変化から洗浄性の評価を行ってきた。この基質上に 油污れのモデルとして高級脂肪酸の超薄膜をラングミュ アーブロジェット法により付着させ、硫酸ドデシルナトリ

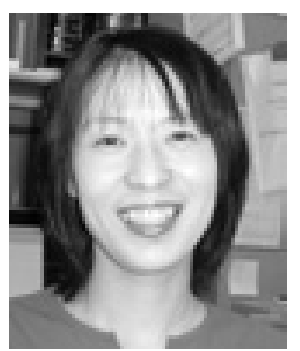

KEIKO GOTOH

京都教育大学教育学部 教授 学術博士 干612-8522 京都市伏見区深草藤森町 1

Tel : 075-644-8318 Fax : 075-645-1734

E-mail : keiko@kyokyo-u.ac.jp 〈専門〉被服学、コイロド界面科学
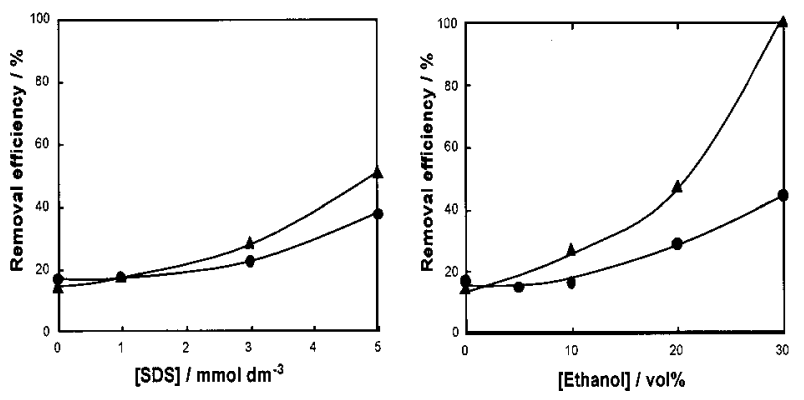

図 1

ポリエチレン $(\mathbf{O})$ およびナイロン $6(\boldsymbol{\Delta})$ 基質からの 高級脂肪酸の脱離率に及ぼす硫酸ドデシルナトリウ ム (SDS) およびエタノール濃度の影響

ウム (SDS) またはエタノールを添加した水溶液中で超音波 洗浄を行った ${ }^{3,4}$ 。得られた結果を図 1 に示す。SDS また はエタノール濃度の増加とともに脱離率が増大する傾向が 認められた。

(1)式の $\gamma_{13}$ と $\gamma_{23}$ は Young の式を用いて次のように与え られる。

$$
\begin{aligned}
& \gamma_{13}=\gamma_{1}-\gamma_{3} \cos \theta_{3 / 1} \\
& \gamma_{23}=\gamma_{2}-\gamma_{3} \cos \theta_{3 / 2}
\end{aligned}
$$

また、 $\gamma_{12}$ は表面自由エネルギーの各成分を用いて次のよ うに書き換えられる5)。

$$
\begin{aligned}
\gamma_{12}= & \gamma_{1}{ }^{\mathrm{LW}}+\gamma_{2}{ }^{\mathrm{LW}}-2 \sqrt{\gamma_{1}{ }^{\mathrm{LW}} \gamma_{2}^{\mathrm{LW}}}+2 \sqrt{\gamma_{1}{ }^{+} \gamma_{1}{ }^{-}} \\
& +2 \sqrt{{\gamma_{2}}^{+}{\gamma_{2}}^{-}}-2 \sqrt{{\gamma_{1}{ }^{+} \gamma_{2}{ }^{-}}^{-}}-2 \sqrt{\gamma_{2}{ }^{+}{\gamma_{1}}^{-}}
\end{aligned}
$$

ここで上添字 LW，十扎よびーはそれぞれ表面自由エネル ギーの Lifshitz-van der Waals 成分、酸成分打よび塩基成分 である。

そこで表面自由エネルギーの各成分や接触角を測定し、 (1) 〜 (4) 式を用いて $\Delta G_{\mathrm{R}}$ を算出し、脱離率との関係をプ ロットした。結果を図 2 に示す。 $\Delta \mathrm{G}_{\mathrm{R}}$ が小さいほど脱離 率が大きくなり、油污れの脱離現象が自由エネルギー変化 で説明できることが明らかとなった。

\section{3. 物体間相互作用理論による固体粒子污れの 再付着現象の解析}

污れの脱離や再付着に伴う自由エネルギー変化は、液体 中に打ける污机基質間の相互作用ポテンシャルエネル ギー曲線からも算出できる。上記のモデル洗浄基質への球 形ポリマー粒子の付着現象をエタノール水溶液中で調べた 


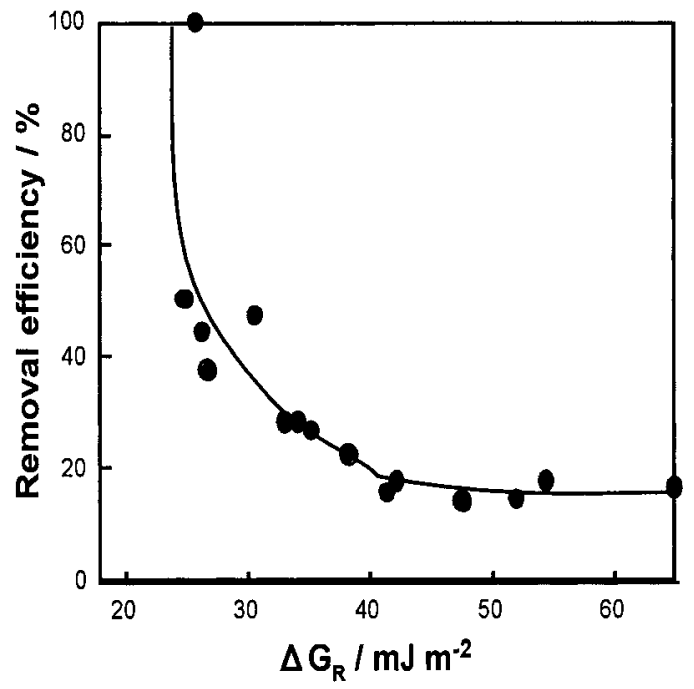

図 2 アラキジン酸の脱離率と脱離の自由エネルギー変化 の関係

研究例 ${ }^{6}$ について述べよう。粒子分散液中にモデル基質を 一定時間垂直に浸漬したときのみかけの平衡付着粒子数と 分散液のエタノール濃度の関係を図 3 に示す。エタノール 濃度が増すと粒子の再付着が抑えられる傾向が認められた。
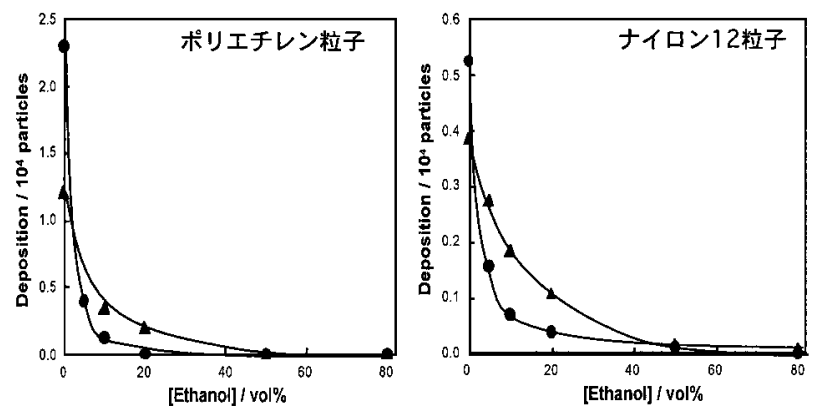

図 3 ポリエチレン $(\mathbf{O})$ 扎よびナイロン $6(\boldsymbol{A})$ 基質への球 形ポリマー粒子の付着数に及ぼすエタノール濃度の 影響

拡張 DLVO 理論によると、巨視的物体間の全相互作用 ポテンシャルエネルギーVTは次式で表わされる。

$$
\mathrm{V}_{\mathrm{T}}=\mathrm{V}_{\mathrm{EL}}+\mathrm{V}_{\mathrm{LW}}+\mathrm{V}_{\mathrm{AB}}
$$

ここで $\mathrm{V}_{\mathrm{EL}}, \mathrm{V}_{\mathrm{LW}}$ および $\mathrm{V}_{\mathrm{AB}}$ はそれぞれ電気二重層相互作 用、Lifshitz-van der Waals 相互作用および酸-塩基相互作 用のポテンシャルエネルギーで、球一平板モデルでは次式 で与えられる

$$
\begin{aligned}
& \mathrm{V}_{\mathrm{EL}}=\frac{\varepsilon \mathrm{a}}{4}\left[\left({\phi_{1}}^{2}+{\phi_{2}}^{2}\right) \ln \frac{\exp (2 \varkappa \mathrm{d})-1}{\exp (2 \varkappa \mathrm{d})}+2 \phi_{1} \phi_{2} \frac{\exp (\varkappa \mathrm{d})+1}{\exp (\varkappa \mathrm{d})-1}\right] \\
& \mathrm{V}_{\mathrm{LW}}=\frac{\mathrm{A}_{132}}{6}\left[\ln \frac{\mathrm{d}+2 \mathrm{a}}{\mathrm{d}}-\frac{2 \mathrm{a}(\mathrm{a}+\mathrm{d})}{\mathrm{d}(\mathrm{d}+2 \mathrm{a})}\right]
\end{aligned}
$$

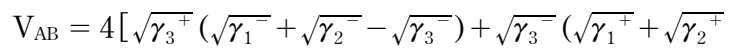

$$
\begin{aligned}
& -\sqrt{\left.{\gamma_{3}}^{+}\right)}-\sqrt{{\gamma_{1}{ }^{+} \gamma_{2}}^{-}}-\sqrt{{\gamma_{1}{ }^{-} \gamma_{2}{ }^{+}}^{2}} \pi \mathrm{a} \lambda \exp \left(\frac{\mathrm{d}_{0}-\mathrm{d}}{\lambda}\right)
\end{aligned}
$$

ここで $\varepsilon は$ は液体の誘電率、 $\mathrm{a}$ は粒子半径、 $x$ は電気二重層
厚さの逆数、 $\mathrm{d}$ は球一平板間の距離、 $\psi$ は外部へルムホル ツ電位、 $\mathrm{d}_{0}$ は表面間の最小接触距離、 $\lambda$ は液体分子の減 衰長さであり、下添字 $1 、 2 、 3$ はそれぞれ粒子、基質、媒 質を表す。 $\mathrm{A}_{132}$ は全 Hamaker 定数

$$
\begin{aligned}
\mathrm{A}_{132}= & -12 \pi \mathrm{d}_{0}{ }^{2}\left(2 \sqrt{\gamma_{1}{ }^{\mathrm{LW}} \gamma_{3}{ }^{\mathrm{LW}}}+2 \sqrt{\gamma_{2}{ }^{\mathrm{LW}} \gamma_{3}{ }^{\mathrm{LW}}}\right) \\
& \left.-2 \sqrt{\gamma_{1}{ }^{\mathrm{LW}} \gamma_{2}{ }^{\mathrm{LW}}}-2 \gamma_{3}{ }^{\mathrm{LW}}\right)
\end{aligned}
$$

である ${ }^{8)}$ 。ここで表面自由エネルギーの各成分および外部 ヘルムホルツ電位 ( 界面動電位) を測定し、全相互作用ポ テンシャルエネルギー曲線を算出した。

一般に、平衡付着量は付着前後のエネルギー差と関係を もつ。そこで付着距離を $1 \mathrm{~nm}$ と仮定してエネルギー極小 值を算出し、平衡付着粒子数との関係をプロットした(罒 4)。エネルギー極小が深いほど付着数が多く、粒子の再付 着は粒子一基質間相互作用に支配されていることがわかっ た。

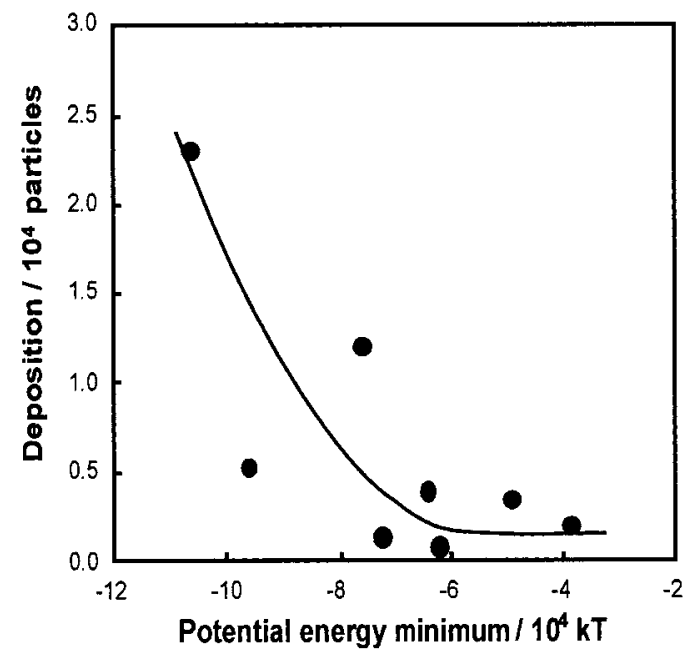

図 4 球形ポリマー粒子の付着数と粒子一基質間の全相互 作用ポテンシャルエネルギー極小值の関係

文献

1) C. A. Miller and K. H. Rancy, Colloids and Surfaces A : Physicochemical and Engineering Aspect, 74, 169 (1993).

2) P. C. Hiemenz, Principle of Colloid and Surface Chemistry, $2^{\text {nd }}$ edn, Marcel Dekker, New York, p. 315 (1986).

3) K. Gotoh and Y. Nakata, J. Oleo. Sci., 53, 489(2004).

4) K. Gotoh, J. Surfactants and Detergents, in press.

5) C. J. van Oss, R. F. Giese and P. M. Costanzo, Clay and Clay Minerals. 38, 151(1990).

6) K. Gotoh, Y. Nakata and M. Tagawa. Colloids and Surfaces A: Physicochemical and Engineering Aspect, in press.

7) K. Gotoh, T. Inoue and M. Tagawa, Colloid Polym. Sci. 262, $982(1984)$.

8) J. D. G. Durán, A. Ontiveros, A. V. Delgado, F. González -Caballero and E. Chibowski, J. Adhesion Sci. Technol. 10, 847(1996). 